\title{
PROBLEMS OF EDUCATION IN THE 21st CENTURY
}

Scientific Methodical Center „Scientia Educologica“, Lithuania, The Associated Member of Lithuanian Scientific Society, European Society for the History of Science (ESHS) and ICASE (International Council of Associations for Science Education)

The articles appearing in this scientific collection are indexed, listed, and abstracted in:

\section{Index Copernicus}

EBSCO: Education Research Complete Education Research Index Database Coverage List "Core" coverage

Central \& Eastern European Academic Source Database Coverage List (EBSCO-CEEAS)

Cabell Publishing, Inc., Directories of Academic Journals

JournalSeek

Ulrich`s Periodicals Directory / Global Serials Directory

The Asian Education Index

SOCOLAR (China Educational Publications Import \& Export Corporation)

List of Science Education Journals

John Lamp's IS Pages: ERA journals in a Field of Research

PECOB (Portal on Central Eastern and Balkan Europe)

GESIS SocioGuide (Knowledge Base SSEE)

Contemporary Science Association/AAP databases

Electronic Serials in Lithuania
List of Journals Recognized by Polish Ministry of Science and Higher Education

WebQualis (QUALIS/CAPES )

trueserials.com

PubGet

Excellence in Research for Australia ERA

(Australian Research Council ARC - Ranking

Journal list)

Zeitschriftendatenbank (ZDB)

Directory of Research Journal Indexing (DRJI)

Academic Keys

Sjournals Index

Open Academic Journals Index (OAJI)

Global Impact Factor (GIF)

Scientific Indexing Services (SIS)

GIGA Information Centre (Electronic Journals

Library)

Polish Scholarly Bibliography /PBN/ (Polska

Bibliografia Naukowa)

European Reference Index for the Humanities and the Social Sciences (ERIH PLUS)

ImpactFactor.pl 